\title{
PREDIKSI STOK DAN PENGATURAN TATA LETAK BARANG MENGGUNAKAN KOMBINASI ALGORITMA TRIPLE EXPONENTIAL SMOOTHING DAN FP- GROWTH
}

\author{
Kristoko Dwi Hartomo*1, Sri Yulianto ${ }^{2}$, Rahmat Abadi Suharjo ${ }^{3}$ \\ 1,2,3 Universitas Kristen Satya Wacana \\ Email: ${ }^{1}$ kristoko@uksw.edu, ${ }^{2}$ sri.yulianto@uksw.edu, ${ }^{3} 672015035 @$ student.uksw.edu \\ *Penulis Korespondensi
}

(Naskah masuk: 07 Maret 2019, diterima untuk diterbitkan: 05 Oktober 2020)

\begin{abstract}
Abstrak
Persaingan bisnis semakin meningkat khususnya dalam bidang retail. Hal ini mengharuskan pemilik melakukan inovasi terhadap bisnisnya. Pemilik swalayan perlu melakukan inovasi untuk melakukan perbaikan tata letak barang dan perbaikan stok, karena konsumen seringkali mengalami kesulitan dalam pencarian barang dan pihak swalayan sering mengalami kekurangan dan kelebihan stok barang. Salah satu hal yang perlu diperhatikan oleh pemilik untuk mempertahankan dan menambah konsumen yaitu dengan melakukan pendekatan dengan konsumen. Pendekatan pada konsumen digunakan untuk mengenali dan memahami perilaku, kebutuhan dan keinginan konsumen. Berdasarkan permasalahan tersebut, maka tujuan penelitian adalah untuk mengoptimalkan pengaturan tata letak barang dan optimalisasi persediaan stok barang. Dalam penelitian ini menggunakan data penjualan yang diolah sehingga menghasilkan informasi untuk pemilik swalayan. Pengolahan data dalam penelitian ini disebut data mining dengan menggunakan algoritma FP-Growth dan Triple Exponential Smoothing. Algoritma FP-Growth digunakan untuk mengetahui pola perilaku konsumen sehingga dapat digunakan untuk pengambilan keputusan dalam penyusunan barang dan algoritma Triple Exponential Smoothing yang merupakan algoritma prediksi digunakan untuk pengaturan stok barang. Dalam penelitian ini dengan menggunakan algoritma FP-Growth menemukan 12 aturan asosiasi, aturan asosiasi yang memiliki nilai lift ratio paling tinggi adalah teh dan gula dengan nilai lift ratio 6.131 dan dengan algoritma Triple Exponential Smoothing diperoleh hasil prediksi pada bulan Januari 2018 adalah 131,141 kg dengan tingkat akurasi MAPE $88,3 \%$.
\end{abstract}

Kata kunci: Analisis, Data Mining, FP-Growth, Triple Exponential Smoothing

\section{STOCK PREDICTION AND ITEM LAYOUT ARRANGEMENT USING A COMBINATION OF TRIPLE EXPONENTIAL SMOOTHING AND FP-GROWTH ALGORITHM}

\begin{abstract}
Business competition is increasing especially in the retail sector. This requires the owner to innovate his business. The shop owner wants to make an invasion to repair goods and equipment, because consumers are in dire need of things and supermarkets often occur. One of the things that need to be considered by the owner to maintain and add consumers is by approaching consumers. Use of information to recognize and understand consumer needs and desires. By overcoming it, the purpose of the research is to regulate the procedures for goods and optimize the preparation of stock items. In this study using processed sales data. Information on information for shop owners. Data processing in this research is called data mining using FP-Growth and Triple Exponential Smoothing algorithms. FP-Growth algorithm to find out user behavior patterns can be used to develop Triple Exponential Smoothing decisions and algorithms which are forecasting algorithms for inventory items. In this study using the algorithm FP-Growth found 12 association rules, which have the highest lift ratio is Tea and sugar with a lift ratio of 6.131 and with Triple Exponential Smoothing algorithm, the forecasting result in January 2018 is $131.141 \mathrm{Kg}$ with 88,3\% MAPE accuracy.
\end{abstract}

Keywords: Analysis, Data Mining, FP-Growth, Triple Exponential Smoothing 


\section{PENDAHULUAN}

Kemunculan pesaing yang begitu banyak membuat pemilik swalayan harus berpikir dan melakukan inovasi agar dapat bersaing. Persaingan sejenis akan mendorong swalayan untuk melakukan inovasi guna mempertahankan dan menambah konsumen perusahaan. Salah satu hal yang perlu diperhatikan oleh perusahaan untuk mempertahankan dan menambah konsumen yaitu dengan melakukan pendekatan dengan konsumen. Pendekatan pada konsumen digunakan untuk mengenali dan memahami perilaku, kebutuhan dan keinginan konsumen. Pengetahuan tentang perilaku konsumen dapat digunakan untuk optimalisasi tata letak barang dan optimalisasi stok barang (Agung dan Nurhadiyono, 2015).

Indomaret, Alfamart, B-Mart, X-Stationery, dan Persada Swalayan merupakan perusahaan retail yang sudah menggunakan pendekatan pola konsumen untuk pengaturan tata letak barang dan stok barang (Bilqisth, 2016) (Tamara, 2016) (Hidayah, 2015) (Utami \& Atmojo, 2017). Masalah yang timbul dari manajemen swalayan adalah pengaturan tata letak barang masih berdasarkan subyektif manajemen saja, jadi terdapat beberapa barang yang seharusnya tidak pantas / cocok disandingkan. Dari tata letak yang terkesan berantakan menimbulkan kesulitan oleh para konsumen dalam pencarian barang. Dengan kondisi seperti itu menyebabkan para konsumen berpindah ke swalayan lain yang memiliki penataan lebih rapi. Pada swalayan ini pengolahan stok barang masih menggunakan perkiraan tanpa memanfaatkan data yang ada, seringkali banyak barang yang kosong dan bahkan terjadi penumpukan barang yang mengakibatkan penghambatan perputaran modal.

Data transaksi penjualan yang terjadi setiap harinya semakin lama semakin menumpuk, data tersebut sangat tidak bermanfaat jika tidak diolah. Data transaksi dapat digunakan untuk mengetahui pola perilaku konsumen. Pengetahuan tentang pola perilaku belanja dapat dimanfaatkan untuk menyusun tata letak barang sehingga memberikan kemudahan bagi konsumen dalam melakukan pembelian dan dapat meningkatkan kemungkinan munculnya keinginan membeli atau impulse buying (Agung dan Nurhadiyono, 2015).

Penelitian sebelumnya memperlihatkan permasalahan yang terjadi pada tata letak barang dan persedian barang dapat mengakibatkan penurunan penjualan maupun menghambat perputaran modal. Riset ini dilakukan untuk menyelesaikan masalah pengaturan tata letak barang dan prediksi stok barang menggunakan algoritma FP-Growth dan Triple Exponential Smoothing. Kedua metode tersebut cocok digunakan dalam pemecahan masalah terkait optimalisasi tata letak barang dan prediksi stok barang.

\section{METODE PENELITIAN}

Dalam penelitian ini ada beberapa langkah yang harus dilakukan agar sesuai dengan tujuan. Tahapan penelitian yang digunakan dapat dilihat pada Gambar 1.

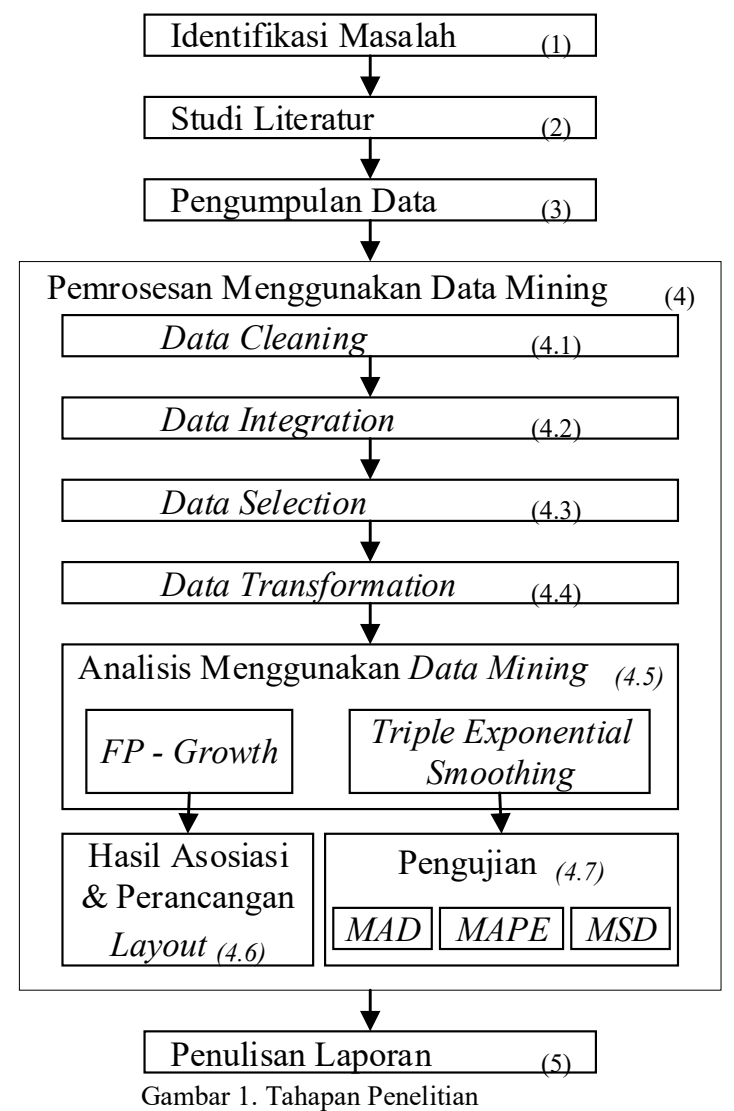

Tahapan penelitian pada gambar 1 diawali dengan tahap 1 yaitu mengidentifikasi masalah, pada tahap ini dilakukan identifikasi terhadap permasalahan yang ada pada penataan barang di beberapa swalayan, masalah yang diketemukan adalah penataan barang dan penentuan barang yang tidak optimal menyebabkan beberapa jenis barang tidak laku bahkan tidak dilihat oleh pelanggan. Masalah tersebut merupakan masalah yang dapat diselesaikan dengan metode market basket analysis dan prediksi.

\subsection{Studi Literatur}

Tahapan selanjutnya adalah tahap 2 yaitu melakukan studi literatur jurnal-jurnal yang memiliki riset area yang sama, berdasarkan penelitian yang berjudul Penerapan Algoritma Apriori dan FP-Growth untuk Mengenali Pola Pembelian Pelanggan pada Elmart Swalayan, penelitian ini menganalisis pola pembelian di Elmart Swalayan. Penelitian ini membandingkan dua algoritma yaitu algoritma Apriori dan FP-Growth, kedua algoritma ini dilakukan pengujian dengan data yang sama dan menghasilkan aturan yang sama pula. Perbedaan dari kedua algoritma tersebut adalah 
waktu komputasi, waktu komputasi dari Algoritma FP-Growth lebih cepat dibandingkan dengan algoritma Apriori. Penelitian ini juga melakukan pengujian lift ratio yang menunjukan bahwa salah satu aturan yang dihasilkan oleh kedua algoritma memiliki kekuatan asosiasi yang besar yaitu 2,06 (Tarigan, Lestari \& Wardhani, 2017).

Berdasarkan penelitian yang berjudul Implementasi Data Mining Dengan Menggunakan Algoritma FP-Growth untuk Menentukan Pola Penjualan Barang Pada Event Tertentu (Studi Kasus: Berkah Swalayan), penelitian ini menganalisis pola perilaku konsumen terhadap pembelian di swalayan Berkah menggunakan data transaksi penjualan. Tujuan dari penelitian ini adalah mengenali pola pembelian pelanggan berdasarkan kecenderungan produk yang muncul dalam data transaksi penjualan serta dapat melihat produk yang sering dibeli oleh pelanggan. Kesimpulan dari penelitian ini yaitu mengidentifikasi barang-barang yang dibeli secara bersamaan kemudian digunakan untuk mengatur tata letak barang. Penelitian ini menghasilkan 6 aturan barang yang saling berkaitan, barang yang paling banyak dibeli oleh pelanggan adalah $\mathrm{ABC}$ Juice Jambu 250ml (Ikhsana, Sihabudin \& Lestari, 2015).

Berdasarkan penelitian yang berjudul Perbandingan Metode Holt Exponential Smoothing dan Winter Exponential Smoothing Untuk Peramalan Penjualan Souvenir. Penelitian ini dilakukan di UD. Fajar Jaya yang merupakan unit usaha dagang yang bergerak pada bidang penyediaan souvenir. Dalam penjualan souvenir, seringkali UD. Fajar Jaya mengalami kekosongan stok souvenir ketika pesanan membludak di waktuwaktu tertentu. Hal ini terjadi karena tidak terdapat analisa dan strategi manajemen stok (tidak dapat memprediksi berapa jumlah optimal souvenir yang harus disediakan) yang dilakukan oleh eksekutif UD. Fajar Jaya. Untuk mengatasi hal tersebut, maka dilakukan prediksi terhadap tingkat penjualan souvenir dengan menggunakan metode Holt dan Winter yang ada pada pengembangan metode Exponential Smoothing (ES). Dari penerapan kedua metode tersebut, kemudian dibuat perbandingan efektifitas metode yang di ukur melalui akurasi data aktual dan hasil prediksi dengan cara mengetahui tingkat kesalahan prediksi. Dari hasil penelitian diperoleh hasil prediksi untuk metode Holt Exponential Smoothing bulan Juli tahun 2017 adalah sebesar 599 item yang mungkin akan terjual dengan tingkat kesalahan prediksi MAPE sebesar $20.5 \%$. Sedangkan untuk prediksi menggunakan metode Winter Exponential Smoothing pada bulan Juli tahun 2017 adalah sebesar 549.6 item yang mungkin akan terjual dengan tingkat kesalahan MAPE sebesar 12.6\% (Utami \& Atmojo, 2017).

Berdasarkan penelitian yang berjudul Prediksi Jumlah Penumpang Pada Siluet Tour And Travel Kota Malang Menggunakan Metode Triple
Exponential Smoothing. Penelitian ini dilakukan prediksi jumlah penumpang pada Siluet Tour and Travel, yaitu salah satu perusahaan yang bergerak dalam bidang jasa tour dan travel. Karena data jumlah penumpang mengandung unsur musiman, prediksi pada penelitian ini menggunakan metode Triple Exponential Smoothing. Tahapan yang dilakukan pada proses prediksi meliputi input data, uji data, proses perhitungan dan output. Hasil dari pengolahan dataset digunakan untuk perhitungan proses ramalan yang menghasilkan $\mathrm{MAPE}=9,86$ alpha $=0,4 \quad m=1$ dengan hasil prediksi jumlah penumpang pada bulan November 2015 adalah 501 (Fitria \& Hartono, 2017).

Berdasarkan lima penelitian tersebut, maka penelitian ini memiliki beberapa perbedaan. Perbedaan mendasar yaitu objek studi kasus yang berbeda dengan riset sebelumnya, pada riset ini menggunakan kombinasi dua algoritma yaitu FPGrowth dan Triple Exponential Smoothing. Kontribusi dalam riset ini sebagai pedoman pemecahan masalah dalam kasus prediksi stok dan tata letak barang.

\subsection{Data Mining}

Riset menggunakan pendekatan data mining, data mining adalah proses yang menggunakan teknik statistik, matematika, kecerdasan buatan dan machine learning untuk mengekstraksi dan mengidentifikasi informasi yang bermanfaat dan pengetahuan yang terkait dari berbagai basis data besar (Kusrini, 2009). Data mining, sering juga disebut knowledge discovery in database (KDD), adalah kegiatan yang meliputi pengumpulan, pemakaian data historis untuk menemukan keteraturan, pola atau hubungan dalam dataset berukuran besar. Keluaran dari data mining ini bisa dipakai untuk memperbaiki pengambilan keputusan di masa depan. Sehingga istilah pattern recognition jarang digunakan karena termasuk bagian dari data mining(Santosa, 2007).

Market basket analysis adalah suatu metodologi untuk melakukan analisis buying habit konsumen dengan menemukan asosiasi antar beberapa item yang berbeda, yang diletakkan konsumen dalam shopping basket (keranjang belanja) yang dibeli pada suatu transaksi tertentu. Tujuan dari market basket analysis adalah untuk mengetahui produk-produk mana yang mungkin akan dibeli secara bersamaan (Han \& Kamber, 2000).

Association rule merupakan teknik data mining untuk mencari pola hubungan dalam data atau basis data yang paling popular adalah Market Basket Analysis (MBA). Association rule adalah salah satu metode yang bertujuan mencari pola yang sering muncul di antara banyak transaksi, di mana setiap transaksi terdiri dari beberapa item (Widodo, 2008).

Ide dari aturan asosiasi adalah untuk memeriksa semua kemungkinan hubungan if-then 
antar item dan memilih hanya yang paling mungkin (most likely) sebagai indikator dari hubungan ketergantungan antar item. Biasanya digunakan istilah antedecent untuk mewakili bagian "jika" dan consequent untuk mewakili bagian "maka". Dalam analisis ini. Antedecent dan consequent adalah sekelompok item yang tidak punya hubungan secara bersama (Santosa, 2007).

Algoritma FP-Growth merupakan salah satu algoritma dari teknik association rule yang dapat digunakan untuk menentukan himpunan data yang paling sering muncul (frequent itemset) dalam sebuah kumpulan data. Pengembangan dari algoritma apriori ini terletak dalam scanning database dan akurasi aturannya. FP-Growth lebih memberikan keuntungan karena hanya dilakukan satu atau dua kali saja scanning database sedangkan apriori perlu melakukan scanning database berulang ulang. Pada apriori akurasi aturannya lebih tinggi daripada FP-Growth, namun karena scanning yang dilakukan berulang membuat kecepatan lebih lambat. Walaupun begitu, kedua algoritma ini memiliki tujuan yang sama yaitu menentukan frequent itemset(Arifin, 2015).

Penggalian itemset yang frequent dengan menggunakan algoritma FP-Growth akan dilakukan dengan cara membangkitkan struktur data tree atau disebut dengan FP-Tree. Metode FP-Growth dapat dibagi menjadi 3 tahapan utama yaitu sebagai (Han \& Kamber, 2006):

- Tahap pembangkitan conditional pattern base.

- Tahap pembangkitan conditional FP-Tree.

- Tahap pencarian frequent itemset.

\subsection{Exponential Smoothing}

Metode prediksi exponential smoothing merupakan sekelompok metode yang menunjukkan pembobotan menurun secara exponential terhadap nilai pengamatan yang lebih tua. Dalam metode ini terdapat satu atau lebih parameter yang ditentukan secara eksplisit, dan hasil pilihan ini menentukan bobot yang dikenakan pada nilai observasi (Makridakis, Wheelwright \& Mcgee, 1999). Triple Exponential Smoothing adalah salah satu jenis metode prediksi exponential smoothing yang merupakan perluasan dari metode Holt (Double Exponential Smoothing). Metode ini dipopulerkan oleh Winter. Metode ini menambahkan nilai faktor musim pada persamaan dasar dari smoothing. Dalam perhitungannya terdapat dua cara yaitu additif dan multipikatif. Disini akan digunakan cara multipikatif, dengan rumus yang ditunjukkan pada persamaan 1, 2, 3,4 (Santoso, 2009):

a. Komponen level estimate

$L_{t}=\alpha \frac{Y_{t}}{s_{s_{-}}}+(1-\alpha)\left(L_{t_{-}} 1+T_{t_{-} 1}\right)$

b. Komponen trend estimate

$T_{t}=\beta\left(L_{t}-L_{t} \quad 1\right)+(1-\beta) T_{t} \quad 1$ c. Komponen Seasonality estimate

$S t=\gamma \frac{\gamma t}{L t}+(1-\gamma) S t-p$

d. Untuk Forecast pada periode ke $\mathrm{p}$

$\hat{\mathrm{Y}} t-p=(L t+p T t) S t-s+p$

Dimana :

$\mathrm{L}=$ Level estimate (dipengaruhi oleh besaran $\alpha$ )

$\mathrm{T}=$ Trend estimate (dipengaruhi oleh besaran $\beta$ )

$\mathrm{S}=$ Seasonality estimate (dipengaruhi oleh besaran

$\gamma)$

$\mathrm{P}=$ Periode musiman

$\hat{\mathrm{Y}}=$ Nilai forecast untuk periode mendatang

Metode ini membutuhkan nilai $\alpha, \beta, \gamma$ sebagai nilai parameter pemulusan. Bobot nilai tersebut lebih tinggi diberikan kepada data yang lebih baru, sehingga nilai parameter yang sesuai akan memberikan ramalan yang optimal dengan nilai kesalahan (error) terkecil. Untuk mendapatkan nilai $\alpha, \beta, \gamma$ yang tepat, pada umumnya dilakukan dengan trial and error (coba-coba) untuk menentukan nilai kesalahan terendah. Nilai $\alpha$ dilakukan dengan membandingkan menggunakan interval pemulusan antar $0<\alpha<1$, yaitu $\alpha(0,1$ sampai dengan 0,9$)$. Metode ini cocok digunakan untuk data yang mengandung unsur trend dan musim dengan pola data tidak stasioner (Santoso, 2009). Metode Exponential Smoothing telah dipergunakan dalam prediksi curah hujan (Hartomo, 2005), harga ternak (Wu, 2016), permintaan pasar (Tratar, 2016), dan produksi kaos (Darmawan, 2018).

Salah satu cara mengevaluasi teknik prediksi adalah menggunakan ukuran tentang tingkat perbedaan antara hasil prediksi dengan permintaan yang sebenarnya terjadi. Ada tiga ukuran yang biasa digunakan, yaitu :

- Mean Absolute Deviation, MAD merupakan rata-rata kesalahan mutlak selama periode tertentu tanpa memperhatikan apakah hasil prediksi lebih besar atau lebih kecil dibandingkan kenyataannya. Secara metematis, MAD dirumuskan seperti pada persamaan 10 (Nasution \& Prasetyawan, 2008).

- Mean Absolute Percentage Error, MAPE merupakan ukuran kesalahan relatif. MAPE biasanya lebih berarti dibandingakan MAD, karena MAPE menyatakan persentase kesalahan hasil prediksi terhadap permintaan aktual selama periode tertentu yang akan memberikan informasi persentase kesalahan terlalu tinggi atau terlalu rendah. Secara matematis, MAPE dirumuskan seperti pada persamaan 11 (Nasution \& Prasetyawan, 2008).

- Mean Squarred Deviation, MSD merupakan ketepatan nilai dugaan model, yang dinyatakan dalam rata-rata kuadrat dari kesalahan, secara matematis, MAD dirumuskan seperti pada persamaan 12 (Nasution \& Prasetyawan, 2008). 


$$
\begin{aligned}
& M A D=\frac{2\left|x_{i}-\bar{x}\right|}{n} \\
& M A P E=\frac{1}{n} \sum_{t=1}^{n}\left|\frac{A_{t}-F_{t}}{A_{t}}\right| \\
& M S D=\frac{\sum_{i=0}^{n}\left(x_{i}-\bar{x}\right)^{2}}{n}
\end{aligned}
$$

\section{HASIL DAN PEMBAHASAN}

\subsection{Pengumpulan Data}

Tahap 3 pengumpulan data, sumber data pada penelitian ini berasal dari data transaksi penjualan pada periode 1 Januari 2016 - 31 Desember 2017. Terdapat dua pembagian data pada penelitian ini yaitu periode data 1 Januari 2017 - 31 Desember 2017 digunakan untuk perhitungan dengan algoritma FP-Growth sedangkan periode data 1 Januari 2016 31 Desember 2017 digunakan untuk perhitungan dengan algoritma Triple Exponential smoothing. Data tersebut akan diproses guna menghasilkan pengetahuan yang dapat digunakan untuk pengembangan strategi bisnis. Data yang diperoleh adalah data transaksi meliputi tabel transaksi, tabel barang, dan tabel detail transaksi. Data yang diperoleh berjumlah 72.645 transaksi dan 11.164 barang.

Tabel 1 adalah tabel barang dari database. Data pada tabel 1 harus diproses. Karena ada data yang tidak benar maka perlu dilakukan proses cleaning.

Tabel 1. Tabel Barang

\begin{tabular}{clllll}
\hline No & Id & Nama & $\begin{array}{c}\text { Harga } \\
\text { Beli }\end{array}$ & $\begin{array}{c}\text { Harga } \\
\text { Jual }\end{array}$ & Satuan \\
\hline 1 & 9447 & 1 & 1 & 2 & PCS \\
2 & 5369 & A & 100 & 200 & PCS \\
3 & 399 & ABC & 4.841 & 6000 & PCS \\
& & 250 & & & \\
& & APL & & & \\
. &. &. &. &. &. \\
11.164 &. & . &. &. &. \\
& & SA & 16000 & 20000 & PCS \\
\hline
\end{tabular}

\subsection{Proses Data Mining}

Tahap 3 adalah proses data mining dimulai dengan tahap data cleaning yaiut melakukan validasi data yang kosong maupun outlier menjadi data yang valid. Data yang digunakan dalam penelitian ini memiliki beberapa record yang tidak sesuai/ salah ketik. Data yang tidak konsisten tersebut diubah/ dilengkapi agar menjadi data yang konsisten.

Tabel 2 adalah tabel barang setelah dilakukan

\begin{tabular}{|c|c|c|c|c|c|}
\hline No & Id & Nama & $\begin{array}{c}\text { Harga } \\
\text { Beli }\end{array}$ & $\begin{array}{c}\text { Harga } \\
\text { Jual }\end{array}$ & Satuan \\
\hline 1 & 399 & $\begin{array}{ll}\text { ABC } & 250 \\
\text { APL } & \end{array}$ & 4.841 & 6000 & PCS \\
\hline 2 & 400 & $\begin{array}{ll}\text { ABC } & 250 \\
\text { JMB. } & \end{array}$ & 4841 & 6000 & PCS. \\
\hline . & . & . & . & . & . \\
\hline 11.162 & 11164 & SA LIPS & 16000 & 20000 & PCS \\
\hline
\end{tabular}
proses cleaning. Pada proses ini dilakukan penghapusan data barang yang sudah tidak dipakai.
Tahap selanjutnya adalah data integration atau proses pengabungan data dari beberapa sumber yang menunjang, namun karena sumber data yang digunakan hanya dari satu database, maka tahap ini tidak dilakukan. Kemudian dilakukan proses seleksi data, proses ini dilakukan untuk memilah data yang digunakan dan tidak digunakan. Setelah dilakukan proses seleksi ini, jumlah data yang digunakan berjumlah 40.940 transaksi dan 3.331 barang. Sejumlah 3.331 barang ini dikategorikan menjadi 25 kategori, 25 kategori tersebut dapat dilihat di tabel 3.

Tabel 3 adalah tabel kategori barang yang akan diteliti beserta jumlah barang yang terdapat dalam kategori tersebut. Kategori susu siap minum memiliki 134 barang. Kategori susu bubuk memiliki 345 barang. Kategori teh siap minum terdapat 98 barang. Kategori teh memiliki 58 barang. Kategori kopi siap minum memiliki 32 barang. Kategori kopi memiliki 77 barang. Kategori soda memiliki 27 barang. Kategori air mineral memiliki 55 barang. Kategori suplemen dan vitamin memiliki 103 barang. Kategori minuman serbuk memiliki 55 barang. Kategori minuman ringan memiliki 137 barang. Kategori adu memiliki 34 barang. Kategori sirop memiliki 15 barang. Kategori mie memiliki 119 barang. Kategori roti memiliki 256 barang. Kategori makanan ringan memiliki 964 barang. Kategori kecap memiliki 37 barang. Kategori saos dan sambal memiliki 42 barang. Kategori bumbu dapur memiliki 78 barang. Kategori tepung memilik 11 barang. Kategori minyak memiliki 32 barang. Kategori gula memilik 11 barang. Kategori beras memiliki 5 barang. Kategori obat memiliki 371 barang. Kategori permen memiliki 235 barang.

\begin{tabular}{cll}
\multicolumn{3}{c}{ Tabel 3. Jenis Kategori Barang } \\
\hline No & Kategori Barang & Jumlah Barang \\
\hline 1 & Susu Siap Minum & 134 \\
2 & Susu Bubuk & 345 \\
3 & Teh Siap Minum & 98 \\
4 & Teh & 58 \\
5 & Kopi Siap Minum & 32 \\
6 & Kopi & 77 \\
7 & Soda & 27 \\
8 & Air mineral & 55 \\
9 & Suplement \& Vitamin & 103 \\
10 & Minuman Serbuk & 55 \\
11 & Minuman Ringan & 137 \\
12 & Madu & 34 \\
13 & Sirop & 15 \\
14 & Mie & 119 \\
15 & Roti & 256 \\
16 & Snack & 964 \\
17 & Kecap & 37 \\
18 & Saos \& Sambal & 42 \\
19 & Bumbu Dapur & 78 \\
\hline
\end{tabular}




\begin{tabular}{cll}
\hline No & Kategori Barang & Jumlah Barang \\
\hline 20 & Tepung & 11 \\
21 & Minyak & 32 \\
22 & Gula & 11 \\
23 & Beras & 5 \\
24 & Obat & 371 \\
25 & Permen & 235 \\
\hline
\end{tabular}

Dalam data transaksi terdapat 40.940 transaksi, data transaksi tersebut tidak digunakan seluruhnya. Data yang digunakan untuk penelitian berjumlah 10.000 transaksi dan diambil secara acak.

Berikutnya dilakukan data transformation, pada tahap ini dilakukan proses pengubahan data transaksi kedalam bentuk data tabular. Pengubahan data ini digunakan untuk pemrosesan data dengan algoritma FP-Growth, untuk metode prediksi data diubah kedalam bentuk data berkala. Data yang digunakan untuk pemrosesan dengan algoritma triple exponential smoothing dapat dilihat pada tabel 4 dan data yang akan digunakan untuk pemrosesan dengan algoritma FP-Growth dapat dilihat pada tabel 5 .

\begin{tabular}{clll}
\multicolumn{4}{c}{ Tabel 4. Data Penjualan Gula } \\
\hline No & \multicolumn{1}{c}{ Bulan } & \multicolumn{1}{c}{ Tahun } & Total $(\mathrm{Kg})$ \\
\hline 1 & Januari & 2016 & 122 \\
2 & Februari & 2016 & 131 \\
3 & Maret & 2016 & 313.5 \\
. &. &. &. \\
. & . &. &. \\
24 & Desember & 2017 & 234.5 \\
\hline
\end{tabular}

Pengubahan data transaksi kedalam bentuk tabular ini dilakukan dengan cara no/ id transaksi dari data yang akan diuji disusun secara horizontal ke bawah dan semua item/ barang yang akan menjadi atribut berbentuk vertikal, sehingga membentuk sebuah tabel dengan data real transaksi dengan nilai biner 0 dan 1,1 disini berarti barang tersebut dibeli dan 0 barang tersebut tidak dibeli. Hasil proses konversi data transaksi ke format tabular dapat dilihat pada tabel 5 .

Tabel 5 adalah data transaksi dalam bentuk data tabular. Data tersebut merupakan data transaksi. Angka 0 pada atribut kategori barang berarti bahwa dia tidak membeli sedangkan 1 pada atribut tersebut berarti membeli.

\begin{tabular}{cccccccc}
\multicolumn{8}{c}{ Tabel 5. Format Tabular Data Penjualan } \\
\hline No & $\begin{array}{c}\text { Id } \\
\text { Transaksi }\end{array}$ & Teh & Kopi &. &. & . & Gula \\
& & & & & & \\
\hline 1 & 21712255 & 0 & 0 &. & $\cdot$ &. & 1 \\
2 & 21706230 & 1 & 1 &. &. &. & 1 \\
3 & 21705325 & 0 & 0 &. &. &. & 1 \\
. &. & & & & & & \\
. &. & & & & & & \\
4094 & 41703204 & 1 & 0 &. &. &. & 0 \\
\hline
\end{tabular}

\subsection{FP-Growth}

Pada tahap ini dilakukan perhitungan menggunakan software RapidMiner. Algoritma FPGrowth membutuhkan dua variabel yang digunakan sebagai standar minimum, dua variabel tersebut adalah support dan confidence. Pada penelitian ini penentuan 2 variabel tersebut dilakukan secara trial and error. Untuk filter pertama pada metode ini adalah nilai supprort, oleh karena itu langkah pertama sebelum melakukan kombinasi dari nilai support dan nilai confidence perlu dilakukan pencarian nilai support dari tiap kategori. Nilai support dari satu kategori (1 item) dapat dilihat pada tabel 6. Tabel 6 menunjukkan nilai support dari tiap item/kategori, nilai yang ada pada tabel 5 digunakan untuk acuan dalam percobaan kombinasi nilai support dan confidence.

\begin{tabular}{clr}
\multicolumn{2}{c}{ Tabel 6. Support 1 Itemset } \\
\hline No & \multicolumn{2}{c}{ Nama Barang } \\
\hline 1 & Snack & 66,33 \\
2 & Permen & 27,77 \\
3 & Susu_Siap_Minum & 27,34 \\
4 & Minuman_Ringan & 23,09 \\
5 & Air_Mineral & 18,85 \\
6 & Susu_Bubuk & 15,99 \\
7 & Roti & 15,98 \\
8 & Gula & 12,02 \\
9 & Obat & 11,97 \\
10 & Teh_Siap_Minum & 11,64 \\
11 & Suplement_Vitamin & 10,77 \\
12 & Mie & 9,85 \\
13 & Teh & 9,54 \\
14 & Kopi_Saset & 5,39 \\
15 & Soda & 4,14 \\
16 & Minyak & 4,13 \\
17 & Sirup & 3,02 \\
18 & Saos_Sambal & 1,87 \\
19 & Minuman_Serbuk & 1,72 \\
20 & Kecap & 1,59 \\
21 & Bumbu_Dapur & 1,41 \\
22 & Kopi_Siap_Minum & 1,09 \\
23 & Madu & 0,62 \\
24 & Tepung & 0,53 \\
25 & Beras & 0,44 \\
\hline & &
\end{tabular}

Percobaan pertama dilakukan dengan nilai support $25 \%$ dan nilai confidence $70 \%$, percobaan pertama menghasilkan aturan asosiasi yang ditunjukkan pada tabel 7. Pada percobaan pertama dengan nilai support $25 \%$ dan confidence $70 \%$ yang dapat dilihat dari tabel 7 menunjukkan bahwa aturan asosiasi belum dapat terbentuk. Aturan asosiasi belum dapat terbentuk dikarenakan nilai support yang terlalu tinggi.

Tabel 7. Percobaan dengan support 25\% dan confidence $70 \%$.

\begin{tabular}{cll}
\hline Size & \multicolumn{1}{c}{ Support } & \multicolumn{1}{c}{ Item 1 } \\
\hline 1 & 0.663 & Snack \\
2 & 0.278 & Permen \\
3 & 0.273 & Susu_Siap_Minum \\
\hline
\end{tabular}

Percobaan kedua menggunakan nilai support $15 \%$ dan confidence $70 \%$, percobaan kedua menghasilkan aturan asosiasi yang dapat dilihat pada tabel 8 . Pada percobaan kedua dengan nilai support $15 \%$ dan confidence $70 \%$ menghasilkan dua aturan asosiasi seperti yang ditunjukkan pada tabel 8. Dua aturan asosiasi tersebut memiliki nilai support dan confidence diatas dari ketentuan. Pembacaan aturan asosiasi yang pertama adalah jika membeli susu siap minum maka membeli snack, aturan tersebut memiliki support 0,200 yang berarti 
memiliki 200 transaksi yang mengandung kedua item tersebut dari keseluruhan total transaksi dan confidence 0.730 yang berarti nilai dari kekuatan aturan asosiasi tersebut adalah $73 \%$ sedangkan Lift 1.101 adalah nilai kekuatan aturan asosiasi sama dengan nilai confidence namun lebih independent.

Tabel 8. Percobaan dengan support $15 \%$ dan confidance $70 \%$

\begin{tabular}{cccccc}
\hline No & Premises & Conclusion & Support & Confidence & Lift \\
\hline 1 & $\begin{array}{l}\text { Susu Siap } \\
\text { Minum }\end{array}$ & Snack & 0.200 & 0.730 & 1.101 \\
2 & $\begin{array}{l}\text { Permen } \\
\text { Permack }\end{array}$ & 0.216 & 0.777 & 1.171 \\
\hline
\end{tabular}

Percobaan ketiga menggunakan nilai support $10 \%$ dan nilai confidance $30 \%$, percobaan ketiga menghasilkan aturan asosiasi yang dapat dilihat pada tabel 9. Pada percobaan ketiga dengan nilai support $10 \%$ dan confidence $30 \%$ menghasilkan 7 aturan asosiasi seperti yang ditunjukkan pada tabel 9.

Tabel 9. Percobaan dengan support $10 \%$ dan confidance $30 \%$

\begin{tabular}{cllllr}
\hline No & Premises & Conclusion & Support & Confidence & Lift \\
\hline 1 & Snack & Susu Siap & 0.200 & 0.301 & 1.101 \\
& & Minum & & & \\
2 & Snack & Permen & 0.216 & 0.325 & 1.171 \\
3 & $\begin{array}{l}\text { Minuman } \\
\text { Ringan }\end{array}$ & Snack & 0.120 & 0.519 & 0.782 \\
& Air & Snack & 0.114 & 0.603 & 0.909 \\
& Mineral & & & & \\
5 & Susu Siap & Snack & 0.200 & 0.730 & 1.101 \\
& Minum & & & & \\
6 & Roti & Snack & 0.120 & 0.752 & 1.134 \\
7 & Permen & Snack & 0.216 & 0.777 & 1.171 \\
\hline
\end{tabular}

Percobaan keempat menggunakan nilai support $5 \%$ dan confidence 50\%, percobaan ketiga menghasilkan aturan asosiasi yang dapat dilihat pada tabel 10. Percobaan keempat dengan nilai support 5\% dan confidence 50\% menghasilkan 12 aturan asosiasi seperti yang ditunjukkan pada tabel 10.

Tabel 10. Percobaan dengan support 5\% dan confidance 50\%.

\begin{tabular}{cllllc}
\hline No & \multicolumn{1}{c}{ Premises } & Conclusion & Support & Confidence & Lift \\
\hline 1 & Minuman & Snack & 0.120 & 0.519 & 0.782 \\
& Ringan & & & & \\
2 & Obat & Snack & 0.062 & 0.520 & 0.783 \\
3 & Mie & Snack & 0.056 & 0.571 & 0.860 \\
4 & Teh Siap & Snack & 0.067 & 0.575 & 0.866 \\
& Minum & & & & \\
5 & Gula & Teh & 0.070 & 0.585 & 6.131 \\
6 & Susu Bubuk & Snack & 0.095 & 0.592 & 0.892 \\
7 & Air Mineral & Snack & 0.114 & 0.603 & 0.909 \\
8 & Susu Siap & Snack & 0.200 & 0.730 & 1.101 \\
& Minum & & & & \\
9 & Teh & Gula & 0.070 & 0.737 & 6.131 \\
10 & Roti & Snack & 0.120 & 0.752 & 1.134 \\
11 & Permen, Susu & Snack & 0.069 & 0.767 & 1.156 \\
& Siap Minum & & & & \\
12 & Permen & Snack & 0.216 & 0.777 & 1.171 \\
\hline
\end{tabular}

Hasil dari percobaan pertama samapai keempat membuktikan bahwa semakin kecil nilai support dan semakin kecil nilai confidance semakin banyak aturan asosiasi yang terbentuk, namun aturan tersebut belum tentu semuanya berguna. Dari hasil percobaan pertama sampai keempat dipilih percobaan keempat sebagai aturan asosiasi yang di pakai untuk penyusunan tata letak barang. Pemilihan aturan asosiasi ini dikarenakan pada percobaan pertama belum terdapat aturan asosiasi yang terbentuk, pada percobaan kedua aturan yang terbentuk masih kurang untuk menyusun skema tata letak barang begitu juga percobaan ketiga, percobaan keempat dinilai cukup untuk mendapatkan skema tata letak barang.

\subsection{Perancangan Layout}

Perancangan layout adalah tahapan setelah ditemukan hubungan antar item (aturan asosiasi). Perancangan/ penataan disini dengan cara menaruh barang aturan asosiasi yang memiliki nilai lift tinggi di belakang dengan tujuan meningkatkan pembelian untuk barang yang memiliki support rendah. Gambar 2 adalah gambar layout di tempat penelitian.
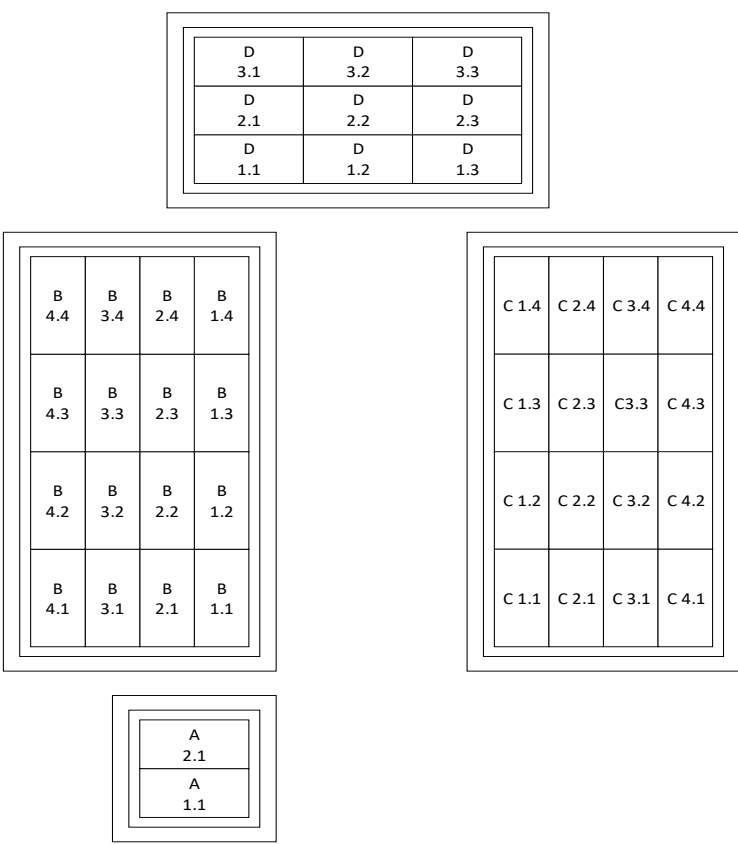

Gambar 2. Layout Rak barang di bagian kebutuhan sehari hari

Gambar 2 adalah layout penataan rak barang di bagian kebutuhan sehari hari. Terdapat 1 etalase dengan bertingkat dengan kode A, 2 rak dengan 4 tingkat berkode $\mathrm{B}$ dan $\mathrm{C}$ dan ada 1 rak 3 tingkat dengan kode D. Penataan barang sebelum dilakukan penelitian ini dapat dilihat pada tabel 11 .

Tabel 11 adalah tabel yang menunjukkan lokasi rak dari setiap kategori barang. Penataan cenderung tidak beraturan/ tanpa melihat kombinasi dari aturan asosiasi. Penataan yang sesuai dengan aturan asosiasi yang sudah terbentuk dapat dilihat pada tabel 12 . 
Tabel 11. Penataan barang sebelum diteliti

\begin{tabular}{ll}
\hline \multicolumn{1}{c}{ Nomor Rak } & \multicolumn{1}{c}{ Nama Barang } \\
\hline B3.1, B3.2, B4.1, B4.2, C3.1, & Snack \\
C4.1, C4.2 & Permen \\
B1.4 & Susu_Siap_Minum \\
B1.1 & Minuman_Ringan \\
B2.1 & Air_Mineral \\
C1.3 & Susu_Bubuk \\
D3.2, D3.3, D4.2, D,4.3 & Roti \\
C4.3, C4.4 & Gula \\
B1.2, B1.3 & Obat \\
A2.1 & Teh_Siap_Minum \\
C2.1 & Suplement_Vitamin \\
A1.1 & Mie \\
B4.3, B4.4 & Teh \\
C1.4 & Kopi_Saset \\
C2.2, C3.2 & Soda \\
C1.2 & Minyak \\
B2.2, B2.3 & Sirup \\
D1.1, D1.2 & Saos_Sambal \\
B2.4 & Minuman_Serbuk \\
C2.3, C3.3 & Kecap \\
B3.4 & Bumbu_Dapur \\
D2.1 & Kopi_Siap_Minum \\
C1.1 & Madu \\
C2.4, C3.4 & Tepung \\
D2.2 & Beras \\
D1.3 &
\end{tabular}

Tabel 12 adalah tabel penataan barang setelah diteliti dengan mengaitkan keterkaitan hubungan asosiasi yang dihasilkan dari algoritma FP-Growth. Tata letak yang baru ini diharapkan dapat meningkatkan penjualan kategori barang yang memiliki support kecil.

Tabel 12. Penataan barang setelah diteliti

\begin{tabular}{ll}
\hline \multicolumn{1}{c}{ Nomor Rak } & \multicolumn{1}{c}{ Nama Barang } \\
\hline C3.1, C3.2, C3.3, C4.1, C4.2, & Snack \\
C4.3, C4.4 & Permen \\
C3.4 & Susu_Siap_Minum \\
C1.4 & Minuman_Ringan \\
C1.2 & Air_Mineral \\
C1.3 & Susu_Bubuk \\
B1.3, B2.3, B3.3, B3.4 & Roti \\
C2.4, C2.3 & Gula \\
D1.2, D1.3 & Obat \\
A2.1 & Teh_Siap_Minum \\
C1.1 & Suplement_Vitamin \\
A1.1 & Mie \\
D3.1, D3.2, D3.3 & Teh \\
D2.3 & Kopi_Saset \\
B2.2, B2.3 & Soda \\
C2.2 & Minyak \\
D2.1, D2.2 & Sirup \\
B1.1, B1.2 & Saos_Sambal \\
B4.4 & Minuman_Serbuk \\
B2.1, B3.1 & Kecap \\
B3.4 & Bumbu_Dapur \\
B1.4 & Kopi_Siap_Minum \\
B3.2, B2.2 & Madu \\
B4.1, B4.2 & Tepung \\
B2.4 & Beras \\
D1.1 &
\end{tabular}

\subsection{Exponential Smoothing}

Algoritma Triple Exponential Smoothing terdapat nilai musim. Data yang digunakan adalah data transaksi gula dari Januari 2016 - Desember 2017. Untuk perhitungan menggunakan metode Triple Exponential Smoothing diperlukan satu variabel $\alpha, \beta, \gamma$. Penentuan variabel $\alpha, \beta, \gamma$ dapat ditentukan secara bebas/ acak, variabel ini memengaruhi hasil perhitungan prediksi yang nantinya dapat diuji dengan beberapa metode pengujian (MSE, MAD, MAPE).

Algoritma 1 adalah proses prediksi dengan metode Triple Exponential Smoothing, proses pertama dilakukan untuk melakukan proses inisiasi peramalan dengan ketentuan bahwa untuk $S_{0}^{\prime}=X_{0}$ dan $S^{\prime \prime}{ }_{0}=X_{0}$ pada baris 7 , apabila nilai $i=1$ untuk setiap data selanjutnya $S_{t}^{\prime}=\alpha X_{t}+(1-\alpha) S_{t-1}^{\prime}$ dan $S^{\prime \prime}{ }_{t}=\alpha S^{\prime}{ }_{t}+(1-\alpha) S^{\prime \prime}{ }_{t-1}$ maka ditentukan nilai $\alpha_{t}=2 S^{\prime}{ }_{t}-S^{\prime \prime}{ }_{t}$ dan nilai $b_{t}=\frac{\alpha}{1-\sigma}\left(S^{\prime}{ }_{t}-S^{\prime \prime}{ }_{t}\right)$ pada baris 14. Proses prediksi dimulai dari indeks data ketiga pada baris 19 karena dalam mencari nilai prediksi pada indeks pertama memerlukan nilai $\alpha_{t}$ dan $b_{t}$, sedangkan nilai $\alpha_{t}$ dan $b_{t}$ belum dapat ditentukan. Demikian pula proses berikutnya pada indeks data kedua untuk mencari nilai prediksi diperlukan nilai $\alpha_{t}$ dan $b_{t}$ dari indeks sebelumnya, demikian seterusnya. Formula yang digunakan untuk menentukan nilai prediksi adalah $F_{\mathrm{t}+\mathrm{m}}=\alpha_{\mathrm{t}}+b_{\mathrm{t}} \mathrm{m}$.

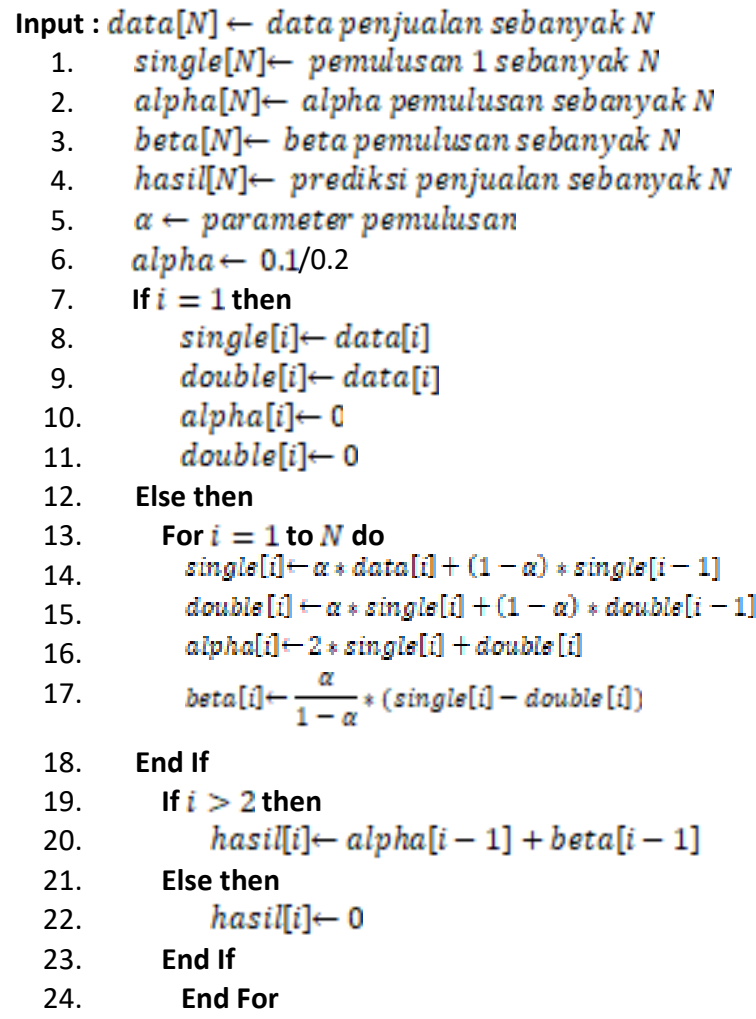

Algoritma 1. Prediksi exponential smoothing

Sebelum melakukan pengujian menggunakan algoritma Triple Exponential Smoothing perlu dilakukan pembacaan pola. Pola pada data penjualan gula dari Januari 2016 - Desember 2017 dapat dilihat pada gambar 3 . 


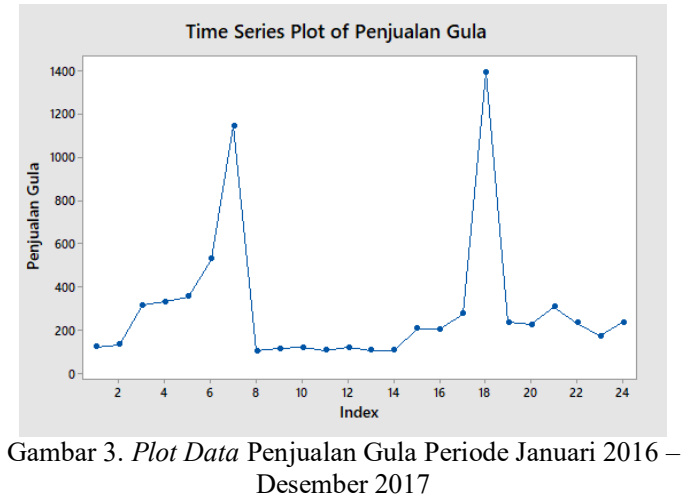

Gambar 3 adalah plot data penjualan gula periode Januari 2016 - Desember 2017. Rentang horizontal menunjukkan rentang waktu sedangkan rentang vertikal merupakan jumlah penjualan gula. Gambar 3 menunjukkan data yang tidak stasioner, data yang tidak memiliki rata rata yang tetap dan cenderung memiliki trend naik. Terdapat lonjakan data yang sangat signifikan, lonjakan data tersebut dipengaruhi dari musim, sehingga data penjualan gula ini memiliki pengaruh musim. Pengujian ini menggunakan $\alpha, \beta, \gamma$ secara acak. Pengujian ini menggunakan software Minitab. Hasil pengujian dari setiap $\alpha$ ditunjukkan oleh tabel 13.

Tabel 13 adalah tabel hasil pengujian menggunakan 3 metode yaitu MAPE, MSD dan MAD. Angka hasil pengujian menunjukkan tingkat galat (error) antara data training dengan model prediksi. Hasil dari 15 kali percobaan menghasilkan model terbaik dengan nilai $\alpha=0,3, \beta=0,01, \gamma=0,01$. Hasil pengujian terbaik menggunakan metode MAPE dengan nilai kesalahan $11,7 \%$ atau dengan akurasi prediksi $88,3 \%$. Grafik model dengan nilai $\alpha=0,3, \beta=0,01, \gamma=0,01$ dapat dilihat pada gambar 4. Tabel 14 adalah hasil pengujian menggunakan metode Triple Exponential Smoothing dengan hasil pengujian pada Januari 2018 adalah 131,141 kg.

Gambar 4 adalah gambar hasil dari perhitungan menggunakan triple exponential smoothing dengan $\alpha=0,3, \beta=0,01, \gamma=0,01$, hasil prediksi pada periode berikutnya adalah $131,1 \mathrm{~kg}$. Hasil dari prediksi menggunakan metode ini dapat dilihat pada tabel 14 .

\begin{tabular}{cllllll}
\multicolumn{7}{c}{ Tabel 13. Hasil Pengujian } \\
\hline No & $\alpha$ & $\beta$ & \multicolumn{1}{c}{$\gamma$} & MAPE & MAD & MSD \\
\hline 1 & 0,1 & 0,1 & 0,1 & 34,9 & 127,4 & 53533,8 \\
2 & 0,1 & 0,5 & 0,9 & 41,7 & 150,5 & 88069,4 \\
3 & 0,1 & 0,3 & 0,2 & 34,7 & 127,8 & 56558,1 \\
4 & 0,1 & 0,05 & 0,2 & 35,8 & 130,5 & 56391,7 \\
5 & 0,4 & 0,5 & 0,2 & 41,7 & 137,3 & 70447,9 \\
6 & 0,2 & 0,2 & 0,2 & 33,7 & 124,6 & 57427,9 \\
7 & 0,3 & 0,2 & 0,5 & 39,5 & 139,2 & 76006,7 \\
8 & 0,2 & 0,2 & 0,5 & 37 & 135,3 & 70453,2 \\
9 & 0,2 & 0,4 & 0,6 & 42 & 145,4 & 80152,7 \\
10 & 0,4 & 0,2 & 0,2 & 36,6 & 128,7 & 64228,2 \\
11 & 0,9 & 0,05 & 137,3 & 39,6 & 137,3 & 74960,3 \\
12 & 0,5 & 0,05 & 0,01 & 33,4 & 122,2 & 57971 \\
13 & 0,2 & 0,05 & 0,01 & 33,3 & 122,1 & 50873,8 \\
14 & 0,01 & 0,05 & 0,01 & 36,5 & 130,8 & 53140 \\
15 & 0,3 & 0,01 & 0,01 & 11,7 & 121,3 & 52056,5 \\
\hline
\end{tabular}

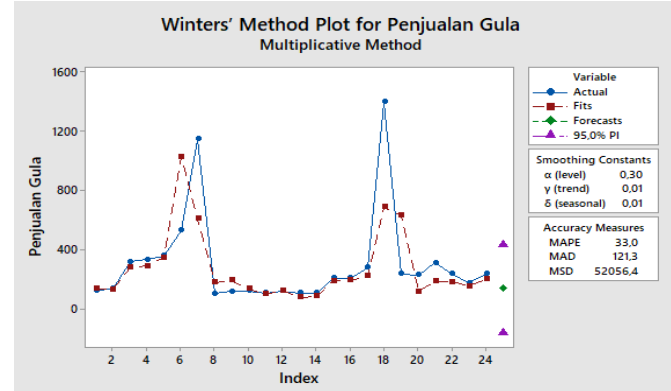

Gambar 4. Grafik Prediksi Pengujian Gula Periode Januari 2016 - Desember 2017

Tabel 14. Hasil Pengujian dengan $\alpha=0,3, \beta=0,01, \gamma=0,01$

\begin{tabular}{clll}
\hline No & \multicolumn{1}{c}{ Periode } & Aktual & \multicolumn{1}{c}{ Prediksi } \\
\hline 1 & Januari 2016 & 122,0 & 131,56 \\
2 & Februari 2016 & 131,0 & 129,75 \\
3 & Maret 2016 & 313,5 & 276,72 \\
4 & April 2016 & 330,5 & 286,54 \\
5 & Mei 2016 & 353,5 & 343,24 \\
6 & Juni 2016 & 528,0 & 1025,40 \\
7 & Juli 2016 & 1143,0 & 604,79 \\
8 & Agustus 2016 & 101,5 & 175,99 \\
9 & September 2016 & 113,0 & 190,87 \\
10 & Oktober 2016 & 117,0 & 133,34 \\
11 & November 2016 & 104,5 & 96,26 \\
12 & Desember 2016 & 118,5 & 120,58 \\
13 & Januari 2017 & 105,5 & 73,46 \\
14 & Februari 2017 & 105,5 & 82,38 \\
15 & Maret 2017 & 205,5 & 187,49 \\
16 & April 2017 & 202,5 & 189,26 \\
17 & Mei 2017 & 275,5 & 217,42 \\
18 & Juni 2017 & 1393,0 & 682,77 \\
19 & Juli 2017 & 234,0 & 627,48 \\
20 & Agustus 2017 & 224,5 & 114,31 \\
21 & September 2017 & 307,0 & 183,60 \\
22 & Oktober 2017 & 232,5 & 179,12 \\
23 & November 2017 & 170,5 & 150,02 \\
24 & Desember 2017 & 234,5 & 195,56 \\
25 & Januari 2018 & & 131,141 \\
& & & \\
\hline
\end{tabular}

\section{Kesimpulan}

\subsection{Kesimpulan}

Berdasarkan hasil pengujian dengan kombinasi algoritma FP-Growth dan Triple Exponential Smooting terhadap data transaksi penjualan, dapat disimpulkan bahwa hasil pengujian menggunakan RapidMiner telah terbukti dapat menerapkan algoritma FP-Growth untuk mendapatkan pola belanja konsumen. Ditemukan 12 aturan asosiasi dengan aturan asosiasi yang memiliki nilai lift ratio paling tinggi adalah teh dan gula dengan nilai lift ratio 6.131 Riset memiliki kontribusi meningkatkan akurasi prediksi dibanding riset sebelumnya, hasil pengujian menggunakan Minitab telah terbukti dapat menerapkan algoritma Triple Exponential Smoothing dengan baik, dan memberikan nilai prediksi pada bulan Januari 2018 adalah 131,141 Kg dengan nilai pengujian error MAPE $=11,7$ (akurasi MAPE $88.3 \%$ ), $M S D=121,3$ dan $\mathrm{MAD}=52056,5$ dengan besaran nilai $\alpha=0,3, \beta=0,01, \gamma=0,01$.

Hasil akurasi prediksi stok dengan metode Triple Exponential Smoothing lebih baik dibandingkan prediksi menggunakan metode 
ARIMA, nilai pengujian error MAPE prediksi dengan metode ARIMA adalah sebesar 31,68\% (akurasi MAPE 68,32 \%). Hasil riset menunjukkan adanya rekomendasi optimalisasi tata letak barang untuk dapat meningkatkan penjualan barang ke depan. Hasil riset juga merekomendasi optimalisasi stok barang berdasarkan prediksi stok untuk efesiensi persediaan barang di gudang.

\subsection{Saran}

Penelitian selanjutnya disarankan menggunakan data jumlah transaksi yang lebih banyak (diatas 10.000 transaksi), penggunaan data lebih banyak dapat meningkatkan akurasi dari aturan asosiasi, cakupan kategori barang lebih luas dan periode data yang digunakan untuk melakukan prediksi lebih lama. Model yang dihasilkan masih bisa ditingkatkan akurasinya dengan menambahkan jumlah periode data history.

\section{DAFTAR PUSTAKA}

AGUNG, M, T. \& NURHADIYONO, B., 2015. Penerapan Data Mining Pada Data Transaksi Penjualan Untuk Mengatur Penempatan Barang Menggunakan Algoritma Apriori, [online] Tersedia di: $<$ http://eprints.dinus.ac.id/16908/2/abstrak_ 16085.pdf $>$ [Diakses 3 Februari 2018]

BILQISTH, S, C., 2016. Analisis Pola Pembelian Konsumen Dengan Algoritma Apriori Pada Indomaret Indraprasta Semarang, [online] Tersedia

di: $<$ http://eprints.dinus.ac.id/18197/1/abstrak 17714.pdf $>$ [Diakses 3 Februari 2018]

DARMAWAN, D. R. et al., 2018. Analisis Peramalan Penjualan dengan Menggunakan Metode Single Moving Average, Weighted Moving Average dan Exponential Smoothing sebagai Dasar Perencanaan Produksi Polo Shirt Pria (Studi Kasus Pada PT. Amanah Garment Bandung).

FITRIA, V, A. \& HARTONO,R ., 2017. Peramalan Jumlah Penumpang Pada Siluet Tour And Travel Kota Malang Menggunakan Metode Triple Exponential Smoothing. Jurnal Ilmiah Teknologi Informasi Asia, V.11, n.1, p.15-20.

HARTOMO, K. D., \& WINARKO, E., 2015. Winters Exponential Smoothing And ZScore, Algorithms For Prediction Of Rainfall. Journal of Theoretical \& Applied Information Technology, 73(1).

HIDAYAH, L., 2015. Rancang Bangun Sistem Informasi Manajemen Persediaan Barang Dengan Menggunakan Metode Exponential Smoothing Di B-MART Swalayan Jombang, [online] Tersedia di :
$<$ http://eprints.unipdu.ac.id/44/> [Diakses 3 Februari 2018]

IKHSANA, Y. et al., 2015. Implementasi Data Mining Dengan Menggunakan Algoritma FP-Growth Untuk Menentukan Pola Penjualan Barang Pada Event Tertentu (Studi Kasus: Berkah Swalayan). Jurnal Aksara Komputer Terapan, V.4, N.2.

MAKRIDAKIS, S. Et al., 1999. Metode Dan Aplikasi Peramalan, Edisi Kedua. Jakarta : Binarupa Aksara.

NASUTION, A.H. \& PRASETYAWAN, Y., 2008. Perencanaan dan Pengendalian Produksi. Yogyakarta : Graha Ilmu.

SANTOSO, S., 2009. Business forecasting metode peramalan bisnis masa kini dengan minitab dan SPSS. Yogyakarta : Elex Media Komputindo.

TAMARA, P, W., 2016. Penentuan Desain Tata Letak Penataan Produk Berdasarkan Market Basket Analysis Dengan Menggunakan Algoritma Apriori di Minimarket Alfamart Patimura Ungaran, [online] Tersedia di : $<$ http://eprints.dinus.ac.id/19859/1/abstrak 18548.pdf $>$ [Diakses 3 Februari 2018]

TARIGAN, T. C. Et al., 2017. Penerapan Algoritma Apriori dan FP-Growth untuk Mengenali Pola Pembelian Pelanggan pada Elmart Swalayan. Jurnal Aksara Komputer Terapan, v5(2). Tersedia di : $<$ https://jurnal.pcr.ac.id/index.php/jakt/artic le/view/775> [Diakses 3 Februari 2018]

TRATAR, L. F. et al., 2016. Demand forecasting with four-parameter exponential smoothing. International Journal of Production Economics, 181, 162-173.

UTAMI, R. \& ATMOJO, S., 2017a. Perbandingan Metode Holt Exponentioal Smoothing dan Winter Exponential Smoothing Untuk Peramalan Penjualan Souvenir. Jurnal Ilmiah Teknologi Informasi Asia, V.11, n.2, p.123-130.

UTAMI, R. \& ATMOJO, S., 2017b. Implementasi Metode Triple Exponential Smoothing Additive Untuk Prediksi Penjualan Alat Tulis Kantor (ATK) Pada "X Stationery". Jurnal Publikasi Dosen, [Online] Tersedia di $\quad<$ http://jurnal.itats.ac.id/wpcontent/uploads/2017/12/sntekpan-ruli.pdf> [Diakses 3 Februari 2018]

WU, L. et al., 2016. Grey double exponential smoothing model and its application on pig price forecasting in China. Applied Soft Computing, 39, 117-123. 